\title{
Vyhodnocení komplexních pozemkových úprav v povodí Litavy
}

JANA UHROVÁ, KAMILA ZÁRUBOVÁ

Klíčová slova: komplexní pozemkové úpravy - plán společných zař́zení - eroze - povodí Litavy

\section{SOUHRN}

V rámci projektu QJ1520268 Nové postupy optimalizace systémů integrované ochrany území v kontextu jejich ekonomické udržitelnosti realizovaného na brněnské pobočce VúV TGM, v.v.i., s počátkem řešení v roce 2015 byla vyžadována prvotní analýza dostupných dat a podkladů jednoho z pilotních povodí, povodí Litavy. Na jednotlivých pobočkách Státního pozemkového úradu (SPÚ) byl proveden sběr dat - projektů komplexních pozemkových úprav (KoPÚ), zejména navržených či realizovaných prvků plánů společných zařízení, které tvoři kostru pozemkové úpravy. Z těchto projektů vznikla ucelená databáze, aktuální k datu 30. 6. 2015. Cílem príspěvku je komplexní analýza získaných dat a vyhodnocení účinnosti stávajícího krajinného pokryvu při ochraně proti vodní erozi na zemědělských půdách podle dnes platných podmínek, ze kterého bude dále vycházet doplňující návrh ochranných opatření v ploše povodí.

\section{ÚVOD}

Pozemkové úpravy jsou v České republice (ČR) za posledních téměř již 25 let stále častěji využívaným nástrojem pro uspořádání vlastnických vztahů k zemědělským a lesním pozemkům s ohledem na hospodaření a na potřeby krajiny. Zejména $v$ rámci komplexních pozemkových úprav se na území řeší nejen vlastnické vztahy, ale v posledních letech mnohem častěji i ochrana před erozí a povodněmi, zprístupnění pozemků i ochrana a tvorba životního prostredí. Takto fungující opatření tvoří společně tzv. plán společných zařízení (PSZ).

Návrh a následná realizace PSZ, který tvoři kostru uspořádání zemědělské krajiny, je jedním z vhodných řešení dvou extrémů počasí, které v posledních několika letech sužují střední Evropu - sucho a prívalové deště. Ty způsobují, že půda po dlouhém období sucha není schopna při príchodu větších srážkových úhrnů vodu dostatečně infiltrovat, většina srážkových vod tak odtéká povrchovým odtokem rychle z povodí, čímž způsobuje velké materiální škody. Je nutné utvořit takové podmínky, aby se voda v krajině zadržela co nejdéle a zpomalil se povrchový odtok. Toho Ize docílit komplexním systémem organizačních, agrotechnických, technických i ekologických opatření, tedy i opatřeními plánu společných zařízení.

Zasáhnout a pozitivně ovlivnit stávající výše popsané problémy, a nejen ty, má právě proces pozemkových úprav, který v České republice vychází z platné legislativy zákona č. 139/2002 Sb., o pozemkových úpravách a pozemkových úradech a o změně zákona č. 229/1991 Sb., o úpravě vlastnických vztahů k půdě a jinému zemědělskému majetku. V rámci projektu QJ1520268 Nové postupy optimalizace systémů integrované ochrany území v kontextu jejich ekonomické udržitelnosti realizovaného na brněnské pobočce VúV TGM, v.v.i., s počátkem řešení v roce 2015 byla vyžadována prvotní analýza dostupných dat a podkladů jednoho z pilotních povodí, a to povodí Litavy. Sběrem projektů KoPÚ z jednotlivých poboček Státního pozemkového úřadu (SPÚ), zejména pak navržených či realizovaných prvků plánů společných zařízení, vznikla ucelená databáze těchto dat, aktuální k 30. 6. 2015. Článek popisuje způsob získání těchto dat, jejich postup zpracování, následnou analýzu i posouzení vlivu stávajícího krajinného pokryvu na ochranu zemědělsky využívané části krajiny $v$ povodí Litavy pred projevy vodní eroze na pưdě.

\section{MATERIÁLY A METODA VEKTORIZACE PSZ}

Projekty KoPú byly brněnské pobočce VÚV TGM, v.vi.., poskytnuty jednotlivými pobočkami Státního pozemkového úřadu a byly podle zvoleného, dále popsaného postupu zpracovány. Následně byla provedena podrobná analýza těchto prvků, to vše s využitím nástrojů GIS.

Veškeré prvky plánu společných zařízení $v$ rozdílných formátech byly následně jednotně vektorizovány v GIS systémech, čímž byla vytvořena databáze navržených či realizovaných PSZ. Každý typ dat vyžadoval individuální přístup, a to jak z důvodu rozdílných zdrojových formátů (shp, dgn, dwg, pdf, jpg), ve kterých byly získány, tak i z důvodu odlišných kvalit, podrobnosti nebo způsobu tvorby výsledných map.

Všechna opatření byla převedena ze získaných typů dokumentací do shapefilů tak, aby nedošlo ke geometrické deformaci, a následně nadefinována v atributové tabulce. Nejméně přesný převod a zákres ochranných prvků PSZ nastal při převodu nafotografovaných dokumentací. Jako hlavní podklad pro vytvoření shapefilu byla použita digitální katastrální mapa (dále jen DKM). DKM se rozumí mapa ve tvaru číselného záznamu svého obsahu, který je možno prostřednictvím výpočetní a zobrazovací techniky znázornit a jinak účelově využít; záznam se pořizuje početním zpracováním měřických údajů a číselným záznamem nového uspořádání pozemků podle schváleného návrhu pozemkových úprav. Souřadnicový systém DKM je S-JTSK. Zásadním kritériem pro zákres daného prvku PSZ bylo jeho parcelní vymezení, jelikož všechna ochranná opatření by měla být parcelně vymezena (technická opatření), a to na obecních pozemcích. Není-li ochranný prvek parcelně vymezen, je jen malá pravděpodobnost, že bude $v$ budoucnu realizován. Byla-li např́klad polní cesta v projektovaném výkresu zakreslena jinak, než bylo její parcelní vymezení, prvek se zakreslil právě podle DKM. K některým katastrálním územím nebyla DKM k dispozici, zejména u projektů ukončených v roce 2015. Neproběhl tedy ještě záznam nového uspořádání pozemků podle návrhu pozemkových úprav. $\checkmark$ tomto prípadě byly prvky PSZ zakresleny podle mapy PSZ (mapa s označením G5 podle Technického standardu dokumentace plánu společných zařízení) a skutečnost, že byl shapefile vytvořen bez DKM, byla zapsaná do atributové tabulky. 


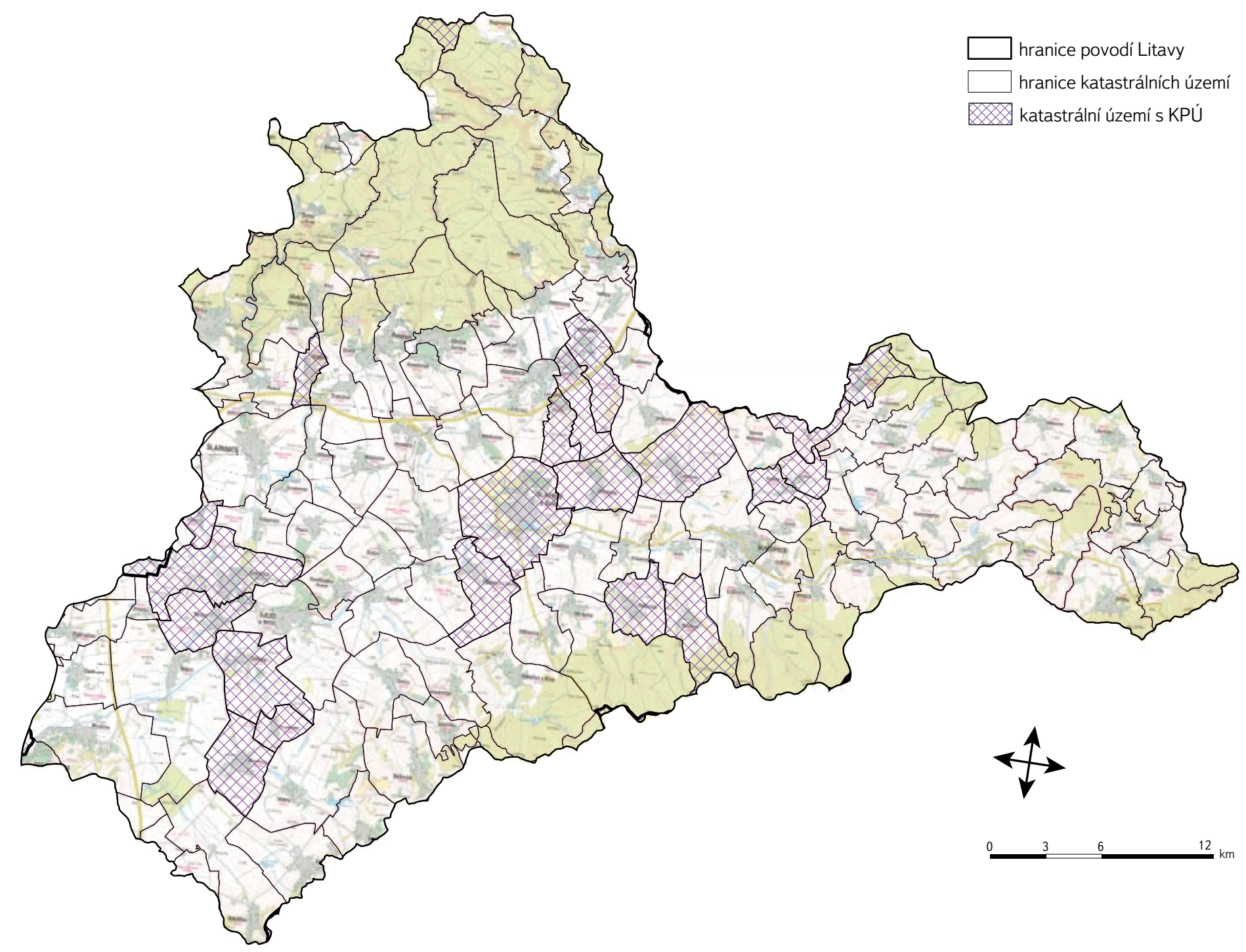

Obr. 1. Lokalizace ukončených KoPú v povodí Litavy

Fig. 1. The localization of completeted land consolidations in the Litava basin

V atributové tabulce bylo u každého prvku zaznamenáno, zda se jedná o stávající opatření (opatření, která se nacházejí v území již před zahájením KoPú), o návrh opatření v rámci KoPÚ, nebo zda stav prvku není specifikován. V některých prípadech došlo u prvků PSZ k překrytí (dochází k překryvu územním systémem ekologické stability - ÚSES s prvky protierozní ochrany - PEO nebo vodohospodářskými opatřeními - VHO; nedochází k překryvu VHO s PEO) např. navržená retenční nádrž je zároveň i biocentrem apod. $V$ tomto případě byl prvek zařazen do více shapefilů podle konkrétního zařazení. Liniové prvky podél polních cest, jako například liniová zeleň nebo cestní príkop, které nemají svá parcelní vymezení, byly popsány a přiřazeny k dané cestě.

Vektorizovaná opatření byla zakreslena $v$ typu geometrie polygon, aby bylo možné vypočítat jejich plošné vymezení (výjimku tvoří propustky, které byly zakresleny bodově). Jednotlivé návrhy opatření, poprípadě objekty plánu společných zařízení byly rozděleny do osmi typů. Byl zvolen systém zápisu prvků jednoho typu vždy do samostatných shapefilů:

- technická ochranná opatření liniového typu - větrolamy, průlehy, meze, príkopy, hrázky, zasakovací pásy a stabilizace údolnic;
— ochranná opatření plošného typu - organizační a agrotechnická opatření, ochranné zatravnění (TTP) a zalesnění;

- nádrže - suché retenční nádrže, nádrže se stálým nadržením a mokřady;

- terasy;

- meliorace - odvodněné plochy;

- ÚSES - interakční prvky, krajinná zeleň, biocentra a biokoridory;

- polní cesty - hlavní, vedlejší a doplňkové polní cesty;

- propustky.

Celkem 57 \% ploch povodí Litavy zaujímají pozemky zemědělsky využívané. Tato plocha je potencionálně ohrožena výskytem vodní eroze půdy, která může způsobit velké škody na samotné půdě, ale i okolní zástavbě. Proto bylo hodnocení protierozní ochrany území provedeno na zájmovém území pomocí pro podmínky ČR verifikovaného stanovení průměrné dlouhodobé ztráty půdy, tzv. univerzální rovnicí ztráty půdy (USLE) [1, 2]. Při stanovování LS faktoru bylo využito programu USLE 2D [3] při algoritmu podle McCoola [4]. U faktorů R a P jsou použity konstantní hodnoty $\left(R=40 \mathrm{MJ} \cdot \mathrm{ha}^{-1} \cdot \mathrm{cm} \cdot \mathrm{h}^{-1}\right.$ a $\left.\mathrm{P}=1,0\right)$. Pro stanovení K faktoru bylo využito údajů z celostátní databáze BPEJ. Na základě hlavní pưdní 
jednotky je přiřazena každému elementu vektorové vrstvy BPEJ hodnota K faktoru [2]. Při stanovení C faktoru byl využit jako podklad celostátně dostupný registr půdních bloků LPIS (Land parcel identification system). Jednotlivé hodnoty C faktoru byly stanoveny v závislosti na klimatickém regionu, který je vyjádren prvním číslem kódu BPEJ [5].

\section{VYHODNOCENÍ KOMPLEXNÍCH POZEMKOVÝCH ÚPRAV}

Jakjiž bylo výše uvedeno, vybraným zájmovým územím pro vyhodnocení komplexních pozemkových úprav je povodí Litavy. Litava je významný levostranný prítok Svratky pramenící ve Chřibech, s délkou toku 58,55 km, jejíz povodí zaujímá plochu $788,36 \mathrm{~km}^{2}$ o průměrném sklonu povrchu $14,01 \%$. V této ploše se nachází nebo do ní jen minimálně zasahuje 144 katastrálních území. Z celkového počtu katastrálních území proběhly KoPÚ ve třiceti z nich a ve třech aktuálně probíhají, což odpovídá 20,8 \% (obr. 1). V plošném vyjádření prošlo procesem pozemkových úprav $139,32 \mathrm{~km}^{2}$ plochy, tedy zhruba $17,7 \%$ plochy povodí. Protože je proces KoPÚ zaměřen na zemědělsky využívané plochy, je tedy třeba se zabývat zemědělsky využívanými plochami, které jsou v povodí Litavy na necelých $57 \%(447,18$ km²), z toho prošlo procesem KoPú téměř $23 \%$ (101,29 km²) zemědělsky využívaných ploch [6].

Z časového trendu získaných dokumentací KoPú pro povodí Litavy (obr. 2) byl zaznamenán nejvyšší počet ukončených komplexních pozemkových úprav v povodí v letech 2003-2005, a to převážně v okresech Vyškov a Brno-venkov. Podíl úspěšně ukončených KoPú v povodí v jednotlivých okresech uvádí obr. 3.

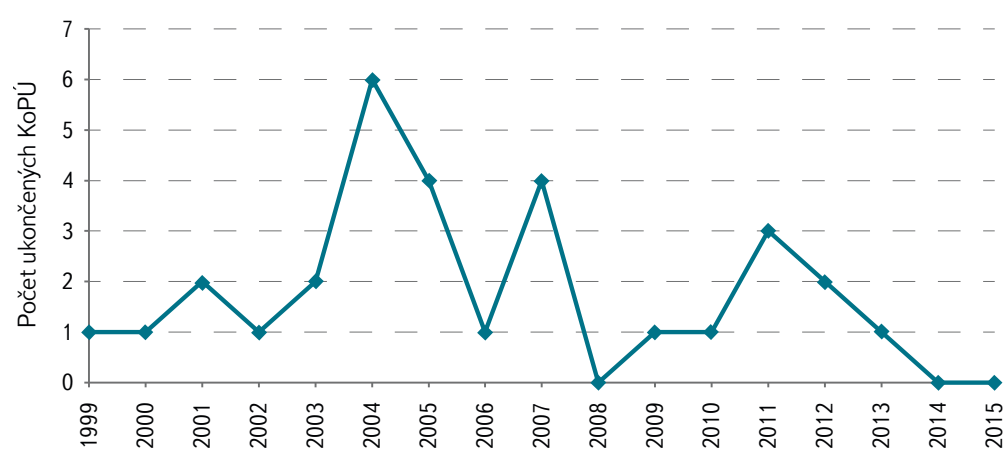

Obr. 2. Časový trend počtu ukončených KoPú v povodí Litavy

Fig. 2. Time-trend in the number of completed land consolidations in the Litava basin

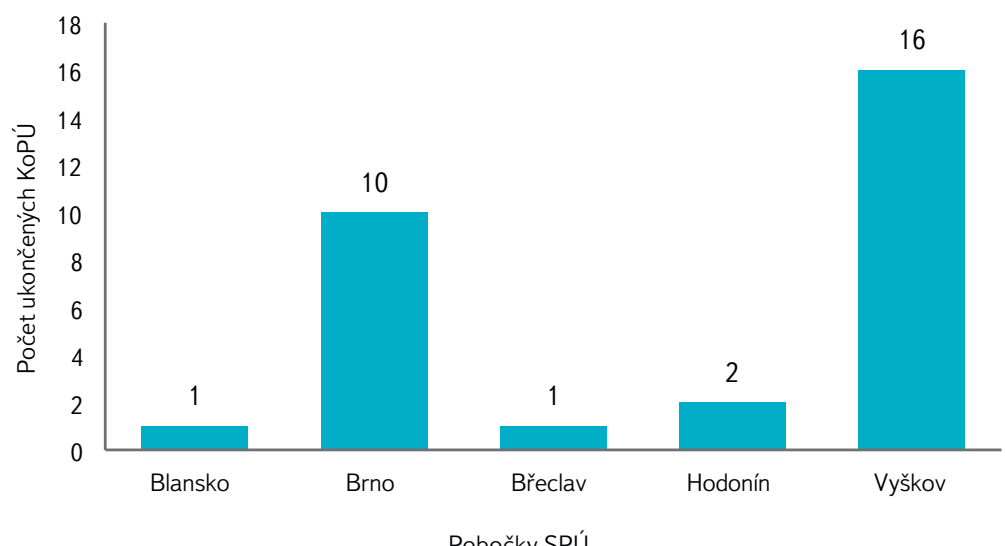

Obr. 3. Počty ukončených KoPú na jednotlivých pobočkách SPÚ

Fig. 3. Numbers of completed land consolidations in each branch of the State Land Office

\section{SKLADBA PRVKU゚ PLÁNU SPOLEČNÝCH ZAŘíZENÍ}

Vyhodnocení jednotlivých prvků zaznamenaných plánů společných zařízení vzniklých při KoPú bylo provedeno na základě dat poskytnutých Státním pozemkovým úřadem. Počet identifikovaných prvků výše popsanou vektorizací i jejich plošnou výměru ukazuje tabulka 1, kde jsou započítány i prvky z právě probíhajících KoPÚ.

Počty prvků jednotlivých opatření bylo velice obtí̌né určit, zejména proto, že zásadním kritériem pro zákres daného prvku PSZ bylo jeho parcelní vymezení, a ne vždy je splněna podmínka 1 prvek = 1 parcela. Zejména u prvků územního systému ekologické stability (ÚSES), kde biocentra zaujímají velkou plochu $\checkmark$ řádu až několika desítek hektarů a biokoridory dosahují délky několika kilometrů a zároveň protínají ostatní prvky PSZ, není možné, aby každý prvek měl pouze jednu parcelu. Nastaly také situace, kdy nebyla DKM k dispozici - jednalo se o nejnovější projekty KoPÚ, které ještě nebyly digitálně zakresleny do katastrální mapy. Podle analýzy zhruba jedna třetina navržených prvků nemá parcelní vymezení, jedná se zejména o prvky ÚSES. Počty jsou tedy pouze orientační. Vyšší vypovídací hodnotu má proto plošná výměra prvků. V tabulce jsou rozlišeny prvky "stávajíci" - prvky, které byly zjištěny v rámci analýzy současného stavu a v zájmovém území se nacházely před zahájením KoPú, prvky "navržené" - prvky, které byly navržené v rámci KoPú a "nespecifikováno" - prvky, jejichž stav nebylo možné ze získaných dat vyčíst.

Mezi nejčastěji navrhované prvky patří bezesporu opatření sloužící ke zpřístupnění pozemků - polní cesty. Polní cesty byly navrženy ve všech k. ú., kde byly zpracovány KoPú. Celkově se jednalo o rozšíření stávající cestní sítě asi o 331 polních cest o celkové výměře téměř 85 ha, z nichž bylo 53 navrhovaných jako hlavních a 278 vedlejších či doplňkových. V třiceti katastrálních územích se tak v rámci KoPÚ různou měrou řešilo približně 700 polních cest zaujímajících zhruba 232 ha plochy řešených katastrů obcí. Cestní sít polních cest dotvářelo 223 propustků, z nichž je 121 nově navrhovaných. Asi v 53 \% proběhlých KoPÚ v povodí Litavy byla navržena technická protierozní opatření (TPEO) na ochranu zemědělského půdního fondu. Nejčastěji navrhovaným ochranným prvkem byly protierozní príḱpopy v počtu 82 návrhů. Ochrannou protierozní funkci, ale i funkci ochrany před př́padným odtokem z plochy povodí mohou jako druhotnou mít ale i navržené polní cesty doplněné príḱpopy. Velmi pozitivním doprovodným efektem realizace ochranných opatření (navržené liniové biotechnické prvky jsou navrhovány s doprovodným ozeleněním) je zvýšení ekologické stability území. Opatření určená výhradně ke zvýšení ekologické stability krajiny na plochách řešených v ukončených KoPú zaujímají rozlohu asi 1023 ha. Hydrologická opatření v podobě suchých nádrží nebo nádrží se stálým nadržením se v projektech na sledovaném území objevuji v počtu 25, z toho jde u devíti nádrží o nové návrhy.

Opatření jako jsou plošná opatření proti vodní erozi (organizační, agrotechnická apod.) nebo odvodněné plochy (meliorace) většinou parcelní vymezení nemají, výjimku mohou tvořit trvalé travní porosty (TTP), které znamenají změny druhu pozemku. Stanovení počtů těchto opatření nemá tedy dostatečnou vypovídající hodnotu, vhodnější je jejich plošné vymezení (tabulka 2). Ochranná opatření plošného typu na zemědělsky využívaných pozemcích zaujímají dle získaných podkladů celkovou rozlohu téměř 2750 ha.

S povodněmi a erozními jevy v povodí, kdy vlivem vzniklého povrchového odtoku dochází k odnosu úrodné části půdního horizontu do nižších poloh, často vznikají materiální škody v zastavěné části obce či dojde k újmě na zdraví obyvatel [7]. Nežádoucí účinky těchto povodní Ize eliminovat vhodně navrženým komplexním systémem protipovodňových a protierozních opatření, který vychází z podrobné analýzy erozních a odtokových poměrů. Řadu vhodných opatření lze realizovat správnou zemědělskou praxí, na kterou je v rámci dotační politiky státu a EU kladen stále větší dưraz dodržováním zákonných opatření stanovených $v$ Kontrole podmíněnosti (crosscompliance) a zejména 


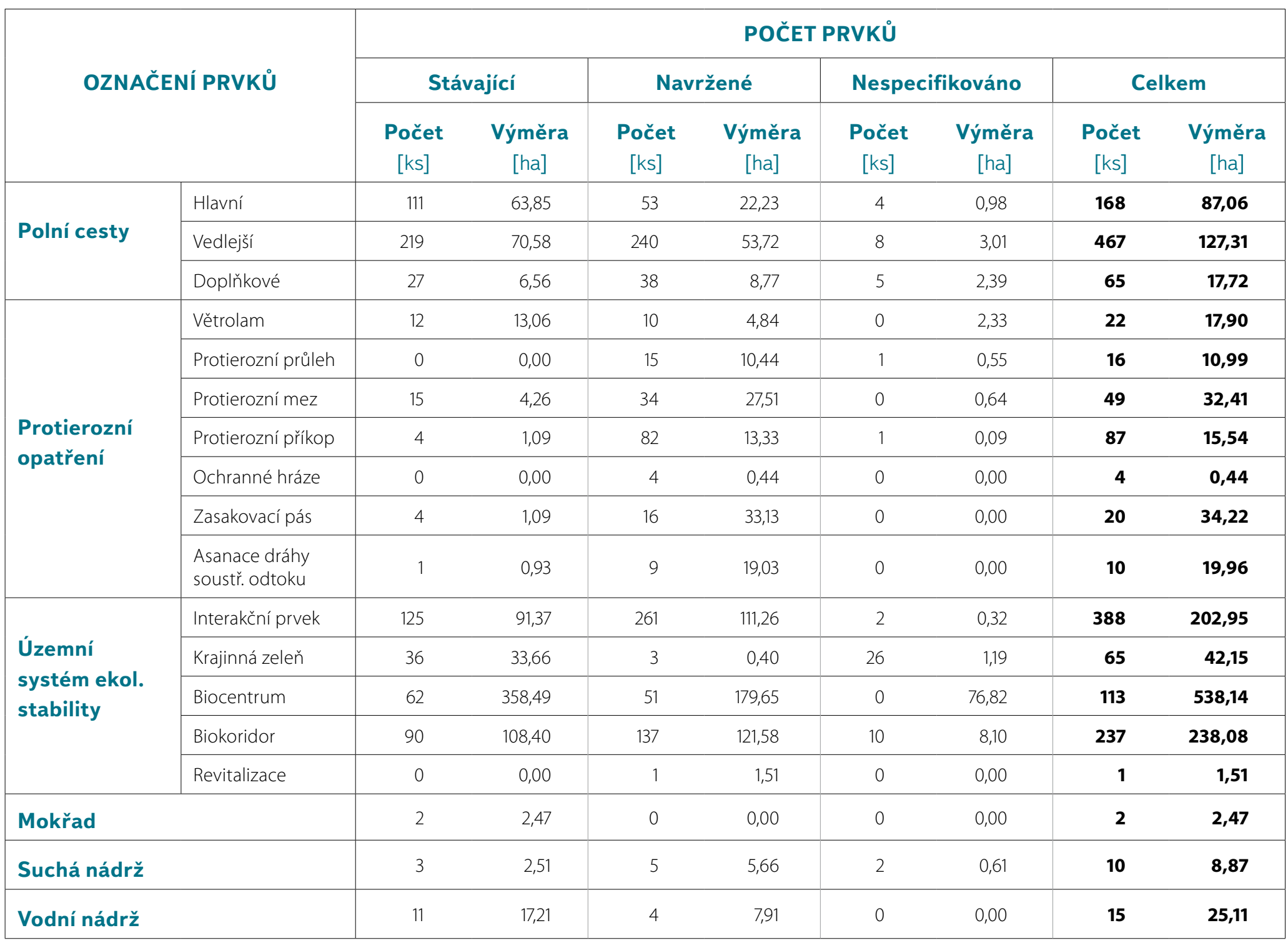

Tabulka 2. Výmèra ochranných opatření plošného typu

Table 2. Acreage of erosion control measures in the area with soil

\begin{tabular}{|c|c|c|c|c|c|}
\hline \multirow{2}{*}{\multicolumn{2}{|c|}{ OCHRANNÁ OPATŘENÍ }} & \multicolumn{4}{|c|}{ VÝMĚRA [ha] } \\
\hline & & \multirow{2}{*}{$\begin{array}{c}\text { Stávající } \\
0,00\end{array}$} & \multirow{2}{*}{$\begin{array}{c}\text { Navržené } \\
2045,13\end{array}$} & \multirow{2}{*}{$\begin{array}{c}\text { Nespecifikováno } \\
0,00\end{array}$} & \multirow{2}{*}{$\begin{array}{r}\text { Celkem } \\
2045,13\end{array}$} \\
\hline \multirow{5}{*}{$\begin{array}{l}\text { Ochranná opatření } \\
\text { plošného typu }\end{array}$} & Organizační opatření & & & & \\
\hline & Agrotechnická opatření & 0,00 & 584,60 & 0,00 & 584,60 \\
\hline & Ochranné zatravnění & 15,21 & 33,09 & 0,29 & 48,30 \\
\hline & Zalesnění & 1,37 & 35,72 & 0,39 & 37,09 \\
\hline & Sady & 34,61 & 0,00 & 0,00 & 34,61 \\
\hline \multicolumn{2}{|l|}{ Terasy } & 3,76 & 0,00 & 0,00 & 3,76 \\
\hline \multicolumn{2}{|l|}{ Odvodněné plochy } & 882,45 & 0,00 & 0 & 882,45 \\
\hline
\end{tabular}


jejích standardů GAEC. Vymezené standardy hospodaření jsou definovány členskými státy Evropské unie v souvislosti se zachováním kvality pưdy, minimální úrovní péče a ochrany vody a hospodaření s ní (na základě rámce stanoveného v príloze č. III nařizení Rady (ES) č. 73/2009). S účinností od 1. 7. 2011 došlo k dalšímu zprísnění podmínek hospodaření, zemědělci musí chránit i tzv. mírně erozně ohrožené půdy. Další opatření se realizují prostřednictvím komplexních pozemkových úprav, především pak budováním společných zařizení.

\section{VYHODNOCENÍ OHROŽENOSTI ÚZEMÍ}

V povodí Litavy je v současné době podle našich analýz téměř $60 \%$ zemědělské půdy potencionálně ohroženo nadlimitním odnosem půdy. Pokud se zaměríme na k. ú. s ukončenými KoPú, tak v těchto katastrech je zemědělské využití plochy průměrně vyšší než je průměr v celém povodí Litavy. Obděláváno je až 72 \% ploch katastrů a k dnešnímu stavu povodí je v k. ú. obcí s ukončenými KoPú stále ohroženo, podle dnes platných limitů v ČR (4 t/ha/rok), až 57 \% ploch zemědělsky využívané půdy odnosem půdy způsobeným plošnou erozí půdy.

Je třeba vzít $v$ úvahu, že se jedná o stav $v$ době, kdy nejsou realizovány všechny navržené protierozní prvky. Protože ale v průběhu let trvání KoPú došlo k vývoji způsobu stanovení jednotlivých vstupních charakteristik pro výpočet hodnoty ztráty půdy i výše limitních odnosů, nebude území dostatečně chráněno ani po realizaci všech v rámci KoPú navržených ochranných protierozních opatření. Zásadní změnu při stanovení erozního ohrožení zaznamenalo navýšení hodnoty $R$ faktoru z původních $20 \mathrm{MJ} \cdot \mathrm{ha}^{-1} \cdot \mathrm{cm} \cdot \mathrm{h}^{-1}$ na dnešních $40 \mathrm{MJ} \cdot \mathrm{ha}^{-1} . \mathrm{cm} \cdot \mathrm{h}^{-1}$, které tak navyšuje stanovenou erozní ohroženost na dvojnásobek. Nejen z těchto zmíněných důvodů ani nemůže být dnešní stav území z pohledu protierozní ochrany vyhovující. Je však velice málo pravděpodobné, že již proběhlé KoPÚ budou revidovány a doplněny o nové návrhy TPEO, a to zejména proto, že zde jsou již vyřešeny vlastnické vztahy a jen těžko by se vyčleňovaly nové pozemky pro prvky PSZ. Snížení erozního smyvu by se však dalo docílit dodržováním vhodných organizačních a agrotechnických opatření.

\section{ZÁVĚR A DISKUZE}

Prvky PSZ analyzované v rámci príspěvku jsou analýzou projektů KoPÚ. Nejde tedy o zaznamenání všech prvků, které se dnes skutečně nacházejí nebo jsou navrhovány v oblasti povodí Litavy.

Celkem 18 \% plochy celé ČR (16\% katastrálních území) prošlo procesem komplexních pozemkových úprav. V rámci JMK prošlo tímto procesem $27 \%$ plochy z celkové rozlohy kraje ( $23 \%$ katastrálních území v kraji) a v povodí Litavy toto procento činí jen 17,7 \%. Nižší procento pokrytí plochy povodí KoPú je způsobeno zalesněním severní části povodí. Při zaměření na zemědělsky využívané plochy prošlo v povodí procesem KoPú 23 \% těchto ploch. S ohledem na skoro 25leté trvání tohoto procesu se zdá, že vidina zpracování celého území není príliš blízkou budoucností. Je třeba ale brát $v$ úvahu urychlení procesu v posledních letech a také jeho stále se zvyšující pozitivní prístup k ochraně krajiny.

Ochrana zastavěných území obcí před dopady zejména povodní z přivalových srážek a s nimi související projevy eroze půdy jsou dlouho akcentovanými problémy, které představují rozsáhlou problematiku. Povodně z prívalových srážek, které charakterizují vysoké srážkové úhrny a doby trvání deště do 180 minut [8], jsou v poslední době vzhledem k častému výskytu výrazným problémem. Souvislosti jsou spatřovány ve změnách extremit klimatických jevů v rámci hydrologického roku, na jedné straně jde o nebývale suchá období způsobená zvýšenými teplotami vzduchu a nedostatkem srážek, na druhé straně jsou zaznamenávány intenzivní srážky spadlé v krátkém časovém intervalu. Tyto skutečnosti poukazují na potřebu navýšení protierozní ochrany navržené obzvláště v začátcích vzniku procesů KoPÚ.
I pres ukončené návrhy komplexních pozemkových úprav je z pohledu erozní i hydrologické ochrany území nejdůležitější samotná realizace navržených prvků. Tisková zpráva Nejvyššího kontrolního úřadu ze dne 1. 6.2015 z kontrolní akce proběhlé na Ministerstvu zemědělství, Státním pozemkovém úřadě v Praze a na Státním zemědělském intervenčním fondu v Praze v rámci již ukončeného Programu rozvoje venkova České republiky na období 2007-2013 uvádí, že od roku 1995 bylo realizováno pouze 9 \% ze všech navrhovaných opatření. Z navrhovaných protierozních opatření bylo realizováno jen 7 \% a z navrhovaných vodohospodářských opatření pouze $10 \%$. Zde hraje největší roli financování prvků PSZ, které v České republice, na rozdíl od okolních států, kde jsou opatření částečně hrazena obcemi i vlastníky pozemků, hradí v plné výši stát. V letech 2007-2014 vynaložilo MZe na pozemkové úpravy z různých zdrojů celkem 13 miliard Kč [9].

\section{Poděkování}

Príspěvek vznikl za podpory projektu QJ1520268 Nové postupy optimalizace systémů integrované ochrany území v kontextu jejich ekonomické udržitelnosti řešeného $\checkmark$ rámci programu KUS Ministerstva zemédělství ČR.

\section{Literatura}

[1] Wischmeier, W.H. and D.D. Smith. Predicting rainfall erosion losses - a guide to conservation planning. Agriciultural Hanbook. 1978, no. 537. US Department of Agriculture, Washington, DC.

[2] Janeček, M. aj. Ochrana zemědělské půdy před erozí: Metodika. Praha: ČZU, 2012. ISBN 978-80 $-87451-42-9$.

[3] Govers, G. and K. Van Oost. USLE2D Homepage: Division of Geography of K.U. Leuven. Geography of K.U. Leuven [online]. 2000 [cit. 2010-09-03]. Dostupné z: http://geo.kuleuven.be/geography/ modelling/erosion/usle2d/index.htm.

[4] Mc Cool, D.K., L.C. Brown, G.R. Foster, C.K. Mutchler, and L.D. Meyer. Revised slope steepness factor for the Universal Soil Loss Equation. Transactions ASAE, 1987, vol. 30, p. 1387-1396.

[5] Kadlec, M. a F. Toman. Závislost faktoru protierozní účinnosti vegetačního pokryvu C na klimatickém regionu, In: Bioklima - Prostředí - Hospodářství, Československá bioklimatologická konference, 2002, Lednice, s. 544-550, ISBN 80-85813-99-8.

[6] Charakteristiky toků a povodí DIBAVOD [online]. 2014 [cit. 2015-20-01]. Dostupné z: http://www. dibavod.cz/24/charakteristiky-toku-a-povodi-cr.html

[7] Drbal, K. aj. Vyhodnocení povodní v červnu a červenci 2009 na území České republiky, Dú Metodika mapování povodňového rizika. VúV TGM: Brno, 2009.

[8] Starý, M. Hydrologie. Studijni opory pro stud. programy s komb. formou studia. Brno: VúT Brno, 2005, 368 s.

[9] Informace z kontrolní akce NKÚ č. 14/40 - Peněžní prostředky určené na úhradu nákladů pozemkových úprav (Tisková zpráva 1. 6. 2015).

\section{Autoři}

Ing. Jana Uhrová, Ph.D.

凶jana_uhrova@vuv.cz

Ing. Kamila Zárubová

凶kamila_zarubova@vuv.cz

Výzkumný ústav vodohospodářský T. G. Masaryka, v.v.i., pobočka Brno

Příspěvek prošel lektorským řízením. 


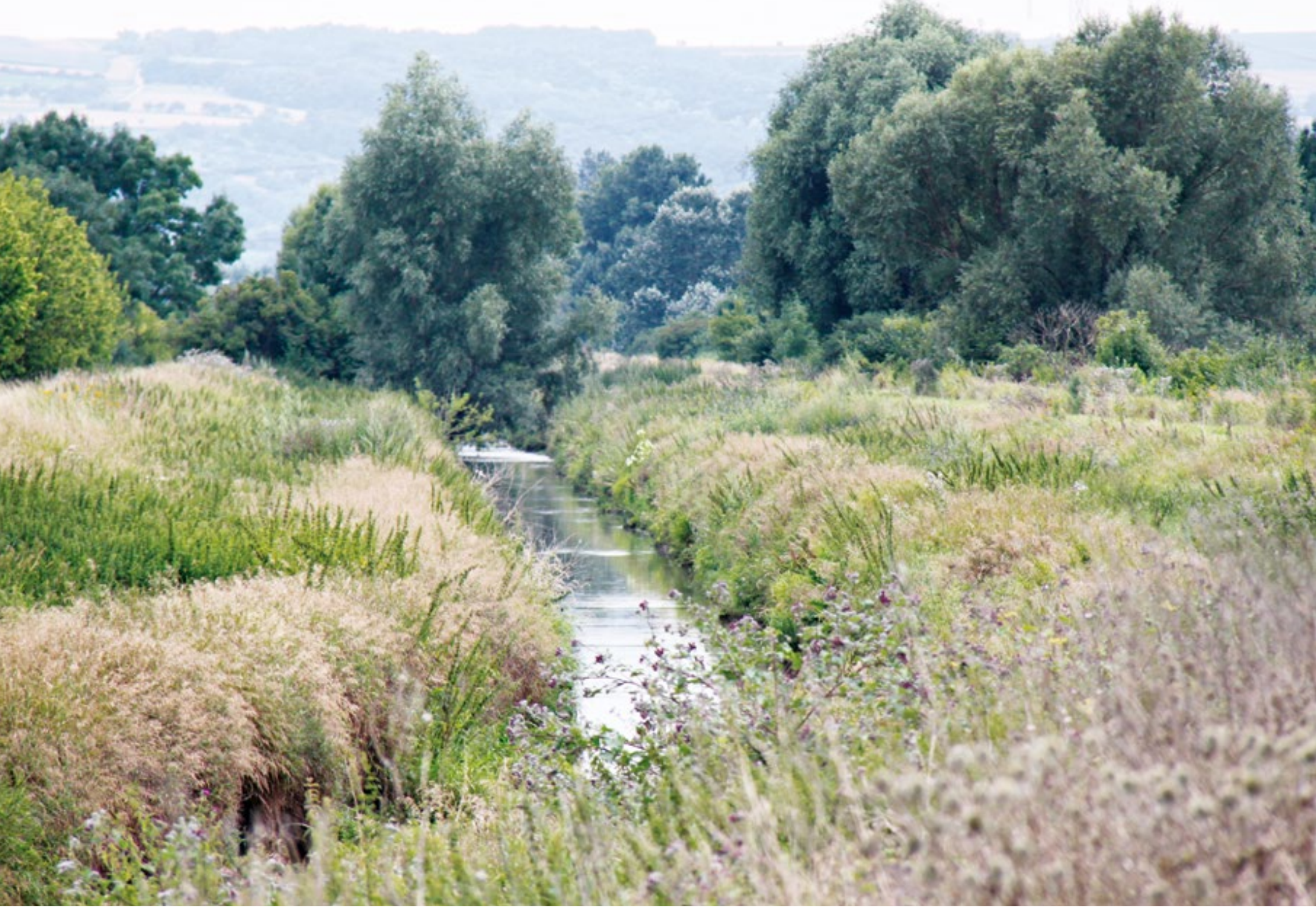

Litava mezi Měnínem a Blučinou

\section{EVALUATION OF THE LAND CONSOLIDATIONS PROCESS IN THE LITAVA BASIN}

\section{UHROVA, J.; ZARUBOVA, K.}

TGM Water Research Institute, p.r.i., Brno branch

Key words: land consolidation - plan of collective equipment erosion - Litava basin

Under the project New procedures of optimization of integrated protection area systems in the context of their economic sustainability, analysis of plans of collective equipment was done within the complex process of land consolidation based on data from all branches of the State Land Office in the Litava basin. Every project of land consolidation was vectorised to shapefile format in ArcGIS geographical information system. As the main base map for the vectorization a digital cadastral map was used, which shows plot demarcation of each measure. If a measure has not plot demarcation, there is only small chance of its implementation. These eight shapefiles were created: technical erosion control measures, area measures, reservoirs, terraces, drainage areas, environmental measures (ÚSES), agricultural roads and culverts. After vectorization and analysis of the measures soil loss by erosion by mathematical model Universal Soil Loss Equation (USLE) was evaluated. The USLE is composed of six factors to predict the long-term average annual soil loss $(G)$. The equation includes the rainfall erosivity factor $(R)$, the soil erodibility factor $(K)$, the topographic factors ( $L$ and $S$ ) and the cropping management factors ( $C$ and $P$ ). The $R$ and $P$ factors

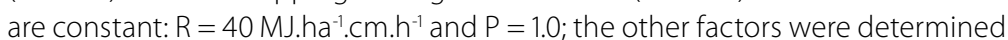
in GIS software based on maps (Land parcel identification system, DEM, etc).

Based on these calculations, currently about $57 \%$ of agricultural land is threatened by erosion. The soil loss by erosion (caused mainly by water) is almost 8 t.haThis situation is a consequence of the fact that the designed measures were not realized in time, mainly because of the lack of funds. According to the Supreme Audit Office of the Czech Republic only 9\% of designed measures were realized.

The process of land consolidations is ever more considered as important tool for landscape water regime, though it mainly solves agriculture and forest land. Water measures - especially in riverbeds - are applied by the state enterprises of the catchment. Therefore cooperation is needed. As the land consolidations are included into the plans of the sub-basins in the Czech Republic, the cooperation will probably be better. 